\title{
Em nome do Pai: o Francisco de Assis de Leonardo Boff
}

\author{
Marcelo Timotheo da Costa* \\ Universidade Salgado de Oliveira, Niterói - RJ, Brasil
}

\section{RESUMO}

O presente texto analisa a imagem de Francisco de Assis construída por Leonardo Boff. Discute-se aqui como o ainda frade franciscano Boff respondeu às sançôes disciplinares a ele impostas pela Santa Sé, reação expressa no livro Francisco de Assis: a saudade do Paraíso (1985). Nessa obra, um exercício memorial inspirado em fontes franciscanas primitivas, Boff vai além da mera celebraçáo da legenda de Francisco de Assis, apresentando o santo medieval como ícone da Teologia da Libertação, crente paradigmático para nosso tempo e patrono das causas populares. Assim, interpretando Francisco de Assis por intermédio dos ideais cristãos liberacionistas, Boff contestou seus adversários, ratificando sua teologia militante. Por fim, ele proclamou projeto político de oposição à ordem estabelecida no Brasil e na Igreja Católica.

Palavras-chave: Teologia da Libertação; Leonardo Boff; Francisco de Assis; Igreja Católica; século XX.

\section{ABSTRACT}

This text analyzes the image of Saint Francis of Assisi created by Leonardo Boff. It is our aim to discuss how the aforementioned theologian, still living as a Franciscan friar, responded to Vatican disciplinary sanctions - reaction expressed in Boff's 1985 book Francisco de Assis: a Saudade do Paraíso (Francis of Assisi: the nostalgia for Paradise). In this cited oeuvre, a memorial exercise inspired by primitive Franciscan sources, Boff goes far beyond the mere celebration of Francis of Assisi's legend, presenting the medieval saint as an icon of Liberation Theology, a paradigmatic believer made patron of popular and progressive causes. Therefore, interpreting Francis of Assisi with the help of Christian liberationist ideals, Boff managed

\section{DOI - http://dx.doi.org/10.1590/2237-101X01703306}

Artigo recebido em 23 de setembro de 2015 e aprovado para publicação em 20 de novembro de 2016.

* Doutor em História pela PUC-Rio e professor do Programa de Pós-Graduação em História do Brasil da Universidade Salgado de Oliveira (Universo). E-mail: marcelotimotheo@uol.com.br. Versão resumida do presente texto foi exposta em conferência intitulada "Liberation Theology celebrates St. Francis", na DePaul University, Chicago, em maio de 2015. Agradeço ao Professor William Cavanaugh pelos honroso convite e gentil acolhida. 
to question his adversaries and eventually maintained his critical viewpoint regarding the Brazilian and Roman Catholic Church established orders.

Keywords: Liberation Theology; Leonardo Boff; Francis of Assisi; Catholic Church; 20th Century.

Para Maria Clara Bingemer: mestra, conselheira, amiga

\section{Introdução}

Francisco de Assis é dos mais célebres santos católicos: ao longo do tempo, conquistou multidões de fiéis e também a admiração de numerosos não crentes. Popularidade, aliás, que lhe garantiu presença no Millennium Top Ten, em enquete de prestigiado semanário norte-americano, em fins dos anos 1990. Reconhecimento que, no mundo acadêmico, fez o assisense motivar significativo número de biografias e estudos especializados, alguns deles notáveis. Entre os exemplos mais recentes, e se levando em conta apenas a historiografia europeia, destaca-se a trinca de livros dos medievalistas Jacques Le Goff, André Vauchez e Chiara Frugoni. ${ }^{1}$ Bibliografia acrescida pelo lançamento do The Cambridge Companion to Francis of Assisi, editado por Michael Robson e reunindo textos de historiadores, teólogos e outros especialistas. ${ }^{2}$

A elevação ao papado do arcebispo de Buenos Aires, Jorge Mario Bergoglio, em março de 2013, ampliou o interesse pela multissecular legenda associada ao santo em questão. Afinal, tão inédita quanto a eleição de cardeal vindo das Américas foi o nome adotado pelo novo papa: Francisco, escolha inspirada no poverello de Assis. ${ }^{3}$

\footnotetext{
${ }^{1}$ Autores, respectivamente, de Saint François d'Assise (obra publicada pela parisiense Gallimard, em 1998 e editada entre nós pela Record, do Rio de Janeiro, em 2001); François d'Assise: entre histoire et mémoire (Paris, Fayard, 2009, ainda sem edição nacional) e Vita di un uomo: Francesco d'Assisi (Turim, Einaudi, 1995, traduzida no Brasil pela paulistana Companhia das Letras, em 2011). Já quanto ao referido Millennium Top Ten, organizado por Time Magazine, confira no sítio do próprio periódico, disponível em: <http://content.time. com/time/magazine/article/0,9171,976745,00.html>. Acesso em: abril 2015.

${ }^{2}$ Cambridge, Cambridge University Press, 2012.

${ }^{3}$ Cumpre notar que, pouco depois do conclave de 2013, Bergoglio, religioso de formação inaciana, fez questâo de esclarecer que a escolha do nome Francisco homenageava o santo de Assis, ao contrário do que haviam apontado alguns repórteres e comentadores, que explicaram a autonomeação do novo pontífice como inspirada em conhecido santo jesuíta homônimo. Por fim, diga-se que o significado, as implicaçóes e os eventuais limites do já célebre "franciscanismo papal" não poderão ser debatidos nessas páginas. Lacuna que, salientada, aponta futura intenção de estudo. Por hora, restringir-me-ei, na conclusão, ao registro da recepção, por Boff, da eleição de Bergoglio e da homenagem deste último a Francisco de Assis.
} 
Permanecendo no universo eclesial católico, porém cambiando agente e sua circunstância, deseja-se acompanhar aqui especial apropriaçáo da canônica franciscana. Tendo Francisco de Assis por referência, o presente texto analisa a imagem deste santo modelada pelo intelectual brasileiro Leonardo Boff, destacado formulador da Teologia da Libertação. Discute-se, pois, como o então frade franciscano, em contexto bastante específico, ao memorializar o fundador de sua Ordem religiosa, fez dele ícone da Teologia da Libertação, apresentando-o como patrono das causas populares. É sobre essa transfiguração do personagem medieval em cristão progressista paradigmático para nossa era - e sobre algumas de suas implicaçóes — que versarão as próximas linhas.

\section{Leonardo Boff: um convertido incomum}

Genézio Darci Boff nasceu em 1938, em Concórdia, Santa Catarina, neto de migrantes italianos. De família religiosa, desde a infância, teve intenso contato com o catolicismo praticado nas colônias agrícolas dessa região do país. Ambiente esse que, unindo migraçáo europeia, piedade católica já romanizada e pequena propriedade rural, irá fornecer à Igreja número significativo de vocaçôes sacerdotais, fazendo que o Sul brasileiro fosse, até há pouco tempo, considerado uma espécie de "celeiro de vocações". ${ }^{4}$

Em 1959, Genézio Boff ingressou na Ordem dos Frades Menores (franciscanos), sendo-lhe conferido o nome religioso de Leonardo. Nomeação que homenageia Leonardo de Porto Maurício (1676-1751), santo franciscano, confessor e pregador popular, tornado padroeiro dos missionários por Pio XI.

Ordenado sacerdote em 1964, Boff completou sua formação acadêmica na Universidade de Munique, doutorando-se em Filosofia e Teologia, em 1970. Poucos meses após regressar ao Brasil, vai até Manaus pregar em retiro destinado a padres e irmãos missionários na floresta tropical. Ali, relata haver vivenciado decisiva crise - decorrente do distanciamento entre a refinada especulação teológica aprendida na Europa e o que lhe reportava seu público amazônico:

(...) a miséria das populaçóes ribeirinhas, o abandono da floresta, os perigos, as demandas de novas respostas para problemas absolutamente novos (...) Senti imediatamente a gravidade do desafio para o pensamento teológico. No terceiro dia de retiro minha crise se havia densificado de tal forma que não conseguia mais fisicamente falar. ${ }^{5}$

\footnotetext{
${ }^{4}$ Vale acrescentar - e apenas lembrando dos nomes mais famosos - que Paulo Evaristo Arns, os primos Aloísio Lorscheider e Ivo Lorscheiter, Cláudio Hummes, Odilo Scherer e o biblista Ludovico Garmus têm a mesma origem de Boff.

${ }_{5}^{5}$ BOFF, Leonardo. Um balanço de corpo e alma. In: BOFF, Leonardo et al. O que ficou... balanço aos 50. Petrópolis: Vozes, 1989, p. 20.
} 
É necessário ter claro que exercícios memorialísticos envolvem seleção. A memória transmuta a experiência, destilando o passado, em vez de simplesmente refleti-lo. ${ }^{6}$ Deve-se ter também em conta que, no universo religioso, tal como no relato formulado por Leonardo Boff, a evocação de vivência traumática, apresentada como turning point de dada trajetória individual, é frequente, sobretudo entre convertidos. Característica igualmente usual no discurso dos teólogos da libertação, que narram episódios semelhantes como inspiradores de suas respectivas reflexôes acadêmicas e açôes pastorais.?

Todavia, mesmo apontado a utilização por Boff deste modelo de oratória, derivado, em última instância, de topoi hagiográficos, cumpre olhar para além do discurso estereotipado. No caso relevante ao presente texto, creio não ser possível negar o choque sofrido pelo franciscano em virtude de seu contato com o que ele próprio, no futuro, chamaria de "Brasil profundo".

A expressão "Brasil profundo", a propósito, foi utilizada para descrever o destino das "Caravanas da Cidadania", conjunto de sete viagens, pelo interior do país, realizadas por Luiz Inácio Lula da Silva, ladeado por políticos, jornalistas e acadêmicos, entre abril de 1993 e julho de 1994. Viagens que, priorizando as regiôes mais empobrecidas da nação, tinham, segundo seus organizadores, o "objetivo explícito de despertar o país para uma campanha nacional de combate à fome e à miséria". ${ }^{8}$ Deslocamentos que, firmando a imagem de Lula como candidato no pleito presidencial de 1994, teriam permitido aos viajantes entrar "na intimidade $\mathrm{d}[\mathrm{as}]$ múltiplas realidades brasileiras". Enfim, ao mais claramente discernível móvel político da empreitada, colocava-se também em curso certa experiência de iniciação, propiciada pelo contato íntimo com realidades nacionais até então mal conhecidas. "Cada caravana funcionou como uma espécie de exame endoscópico que os médicos costumam fazer", definiu Leonardo Boff, participante da derradeira Caravana. ${ }^{10}$ Viagem esta que, sintomaticamente, seguiu o rio São Francisco, descendo de suas nascentes, em Minas Gerais, até Petrolina, no estado de Pernambuco. É o próprio Boff, já desligado de sua Ordem religiosa, mas ainda tributário do legado de Assis, que afirma:

Ia ao encontro de um símbolo, o de um dos mais fortes arquétipos da alma brasileira, a figura de São Francisco, o pobrezinho, o passarinheiro, o amigo dos condenados da terra, que emprestou seu nome ao rio mais afetuoso do povo brasileiro, chamado carinhosamente de Velho Chico. ${ }^{11}$

\footnotetext{
${ }^{6}$ Ver LOWENTHAL, David. The past is a foreign country. Cambridge: Cambridge University Press, 1985, p. 204.

${ }^{7}$ Ver, por exemplo, BOFF, Leonardo; BOFF, Clodovis. Como se faz Teologia da Libertação? Petrópolis: Vozes, 1986, p. 11-12.

${ }^{8}$ KOTSCHO, Ricardo. “Apresentação". In: KOTSCHO, Ricardo et al. Viagem ao coração do Brasil. São Paulo: Scritta, 1994, p. XVI.

${ }^{9}$ Ibidem, p. X.

${ }^{10}$ BOFF, Leonardo. Encontro com o Brasil profundo. In: KOTSCHO, Ricardo et al. Viagem ao coração do Brasil, op. cit., p. 159.

${ }^{11}$ Ibidem, p. 163.
} 
Deste deslocamento, comparado ao ato de auscultar as entranhas do país, teria resultado "o encontro com o Brasil profundo". ${ }^{12}$

Retorno à temporada amazônica de Leonardo Boff, em 1970, temporada passada pouco após anos de afastamento do país. Período apresentado por nosso autor, em texto autobiográfico já lembrado, como de abrupta passagem entre universos sobremaneira distintos e distanciados: aquele que deixara no Velho Continente e o que encontrara nos trópicos. Por tudo que foi dito, ainda que se leve em conta a capacidade da memória de alterar experiências, aquela vivida por Boff, em Manaus, deve, com efeito, ser considerada fundamental para que o teólogo se empenhe, daí para a frente, na construção de eclesiologia combatente, contestadora.

Para melhor compreender essa proposição, confirmando o conflito entre o preparo teórico recebido pelo frade franciscano na Alemanha e o cotidiano de parte significativa dos brasileiros à mesma época, é pertinente recuar no tempo. Recordar os rígidos padrôes vigentes nos seminários até o Concílio Vaticano II (1962-1965), modelo de formação ao qual Boff e todo o clero católico, desde o Concílio de Trento (1545-1563), foram submetidos. E o jargáo eclesial característico da romanizaçáo tridentina é revelador. Os seminários foram pensados como "fortalezas" de Deus - locais idealmente afastados "do mundo secular", tomado por corrupto e pernicioso. Portanto, os citados estabelecimentos de ensino buscavam, ao máximo, apartar seus internos da sociedade extramuros. Afastamento confirmado, inclusive, pela renomeaçáo cerimonial do candidato à vida religiosa, como ocorreu com Genézio Boff, feito Leonardo. No caso do antigo cerimonial franciscano de admissão, a cisão entre existências anterior e posterior à entrada no seminário era enfatizada: ao ser renomeado, o postulante, além do nome de batismo, abandonava também suas vestes seculares, adotando o hábito de frei já morto.

Resumindo: não é de se espantar que alguns dos presbíteros e religiosos, privados (em muitos casos, desde tenra idade) de maior contato com a realidade cotidiana durante sua longa formação, fossem surpreendidos e questionados em suas certezas pelo que observavam na "Cidade dos Homens", quando finalmente enviados a seus trabalhos pastorais.

Já foi suficientemente apontada a relação entre o pensamento progressista cristão latino-americano e a situaçáo de pobreza vivida por milhóes de pessoas naquele continente. ${ }^{13}$ No que tange à Teologia da Libertação, entre seus formuladores e analistas, tornou-se consensual demonstrar como a percepção do subdesenvolvimento econômico e da injustiça social dele decorrente fomentou nova consciência cristã. Consciência que, a despeito das diferenças existentes entre os teólogos da libertação, vai produzir inovaçôes profundas, compartilhadas por todos eles. Entre elas, Michel Löwy enumera a negaçáo da separaçáo entre

\footnotetext{
${ }^{12}$ Ibidem, p. 160.

${ }^{13}$ Ver, por exemplo, OLIVEROS MAQUEO, Roberto. Liberación y teología: génesis y crecimiento de una reflexión (1966-1976). Cidade do México: CHR, 1977, p. 52-101.
} 
histórias humana e divina, partição baseada no dualismo grego; duras críticas ao sistema capitalista, tomado por iníquo e moralmente contrário ao espírito do cristianismo; a crença na libertação histórica dos homens como prenúncio da libertação escatológica; utilização do marxismo "como instrumento socioanalítico a fim de entender as causas da pobreza, as contradiçôes do capitalismo e as formas de luta de classe". ${ }^{14}$

Sem dúvida, há espaço para múltiplas controvérsias nestas e em outras proposiçóes dos teólogos da libertação. Entre as muitas celeumas, a que alcançou maior repercussão - dentro e fora do orbe católico - foi o uso do instrumental marxista por religiosos. Afinal, os postulados teóricos e o regime político e econômico advogado por Karl Marx foram anatematizados, nos mais incisivos termos, pelo Magistério, em reiteradas ocasiôes. Assim ocorreu na passagem dos vinte anos da Revoluçáo Vermelha, quando Pio XI, na encíclica Divini Redemptoris, de março de 1937, definiu o comunismo como "intrinsecamente perverso". ${ }^{15}$ Declaração, seja lembrado, feita apenas três décadas antes da gênese da Teologia da Libertação. Em termos históricos, portanto, pouco tempo transcorrera entre o anátema romano e o uso do marxismo por Boff e outros teólogos. Intervalo ainda mais breve se é assumida a especial rationale cronológica da Igreja, orgulhosa em sua autocelebrada bimilenaridade. Como, entáo, aos olhos de muitos, assumir métodos idealizados por pensador que afirmara ser a religiāo "ópio do povo"? 16

Para justificar institucional e publicamente semelhante câmbio - isto é, transformar ideias antes condenadas e temidas em instrumental analítico válido para informar e formar reflexão e práticas cristãs —, os teólogos liberacionistas discernem diferentes marxismos. Desvinculam-se, por exemplo, das críticas em relação à religião emanadas da Academia de Ciências de Moscou. E assumem a validade do método marxista de análise social, visando a elaboração de estratégias e de propostas políticas classificadas de emancipadoras. Operando desta forma, os teólogos da libertação declaram não rebaixar a experiência religiosa em nome da militância política. Para eles, está em jogo buscar a "eficácia" da fé, sendo esta última concebida como superior ao materialismo histórico. Hierarquização explicitamente garantida por Boff:

$\mathrm{O}$ que propomos não é a teologia dentro do marxismo mas a utilização do marxismo (materialismo histórico) pela teologia. A teologia é o referente maior, e não o marxismo; ela possui sua gramática própria, mas, quando busca eficácia libertadora no nível social, se apropria, à sua maneira, da contribuiçáo da racionalidade marxista e elabora a sua síntese à luz de seus próprios critérios teológicos. ${ }^{17}$

\footnotetext{
${ }^{14}$ LÖWY, Michael. A guerra dos deuses: religião e política na América Latina. Petrópolis: Vozes, 2000, p. 61. ${ }^{15}$ IGREJA CATÓlICA. Documentos de Pio XI. São Paulo: Paulus, 2004, p. 589.

${ }^{16}$ Expressão que Marx utilizou no texto Sobre a Crítica da Filosofia do Direito de Hegel (1844). Cf. in LÖWY, Michael. A guerra dos deuses: religião e política na América Latina, op. cit., p. 13.

${ }^{17}$ In: BOFF, Leonardo. O caminhar da Igreja com os oprimidos: do Vale de Lágrimas à Terra Prometida. Pe-
} 
A procura pela desejada "eficácia libertadora", unindo reflexão de fé e interpretação marxista, levou Leonardo Boff a empreender ação fundamental para a presente análise. Refiro- me à reformulação da tradicional ideia de conversão religiosa. Reformulação, como será visto mais tarde, exemplificada pelo Francisco de Assis concebido pelo teólogo brasileiro.

\section{A Teologia Política de Leonardo Boff}

\section{De volta às fontes franciscanas}

Propôe-se, aqui, como antecipado, que Leonardo Boff apontou, em Francisco de Assis, atuação precursora na defesa de causas que, séculos depois, seriam abraçadas pela Teologia da Libertação. Nas linhas seguintes, buscar-se-á entender como Boff, apelando aos primeiros relatos franciscanos, definidores da imagem tradicionalmente associada ao mistico de Assis, conferiu sentido novo às citadas narrativas. Desta forma, Boff transformou Säo Francisco em espécie de padroeiro do cristianismo liberacionista latino-americano. Para ilustrar esse engenhoso movimento empreendido pelo intelectual brasileiro, analisarei Francisco de Assis: a saudade do paraiso, de $1985 .{ }^{18}$ Antes, porém, é conveniente situar melhor tal obra na bibliografia de nosso autor.

\section{Uma dupla de ensaios engajados}

Retornado da Alemanha, em 1970, Leonardo Boff assume a cátedra de Teologia Sistemática no Instituto Teológico Franciscano, centro de formação de sua Ordem religiosa, situado em Petrópolis, na serra fluminense. Docência e pesquisa acumuladas com o posto de redator de dois prestigiosos periódicos especializados, a revista internacional Concilium (em sua edição em língua portuguesa) e a Revista Eclesiástica Brasileira. Ainda em 1970, ele é incorporado ao conselho da Vozes, casa editorial franciscana, dotada de vasto catálogo e rede de distribuição nacional de grande capilaridade. É deste lugar social privilegiado que irá trabalhar na divulgação e ampliação da então nascente Teologia da Libertação (idealizada primeiro, poucos anos antes, pelo padre peruano Gustavo Gutiérrez). Esforço enfaticamente reiterado na produção bibliográfica do brasileiro.

trópolis: Vozes, 1998, p. 287, grifo meu. A primeira edição desta obra foi realizada pela Codecri, editora de O Pasquim, em 1980.

${ }^{18}$ Cumpre observar que a quarta e mais atual edição desta obra, publicada em 1999 , passou a ter o subtítulo " $o$ homem do Paraíso". Houve igualmente algumas poucas alteraçôes no seu texto, permanecendo sua mensagem principal. Para citaçóes, seguirei a forma original de 1985. 
Em 1972, Boff publica Jesus Cristo libertador, considerada obra inaugural da nova eclesiologia no Brasil..$^{19} \mathrm{O}$ subtítulo — ensaio de Cristologia crítica para o nosso tempo — sintetiza o que está em questão: atualizar o pensamento do personagem principal da fé professada pelo frade franciscano, interpretação levada a termo pela teologia militante que este último ajudava a estabelecer. Tomando apenas um exemplo deste livro, lembro da maneira pela qual Boff explica aquela que, para ele, seria a ideia de conversão proposta pelo Jesus histórico:

(...) não somente mudança de convicção (teoria) mas principalmente mudança de atitude (prática) (...) do homem como ser concreto envolvido por uma rede viva e ativa de relaçóes. Conversão é, positivamente, a produção de relaçóes modificadas em todos os níveis da realidade pessoal e social de tal forma que concretize libertaçôes e antecipe o Reino [de Deus na terra]. O pessoal vem dialetizado pelo social e vice-versa. ${ }^{20}$

Dada a natureza do presente texto, não será possível analisar detidamente Jesus Cristo libertador. A partir do trecho disposto acima, cabe tâo somente frisar dois pontos relativos à estratégia discursiva empregada na citada obra. Nela, é expresso determinado programa religioso e político. Programa de libertaçâa cuja origem, para Boff, remontaria ao próprio mestre e taumaturgo judeu, proclamado Messias pela fé nele fundada. Plataforma política e religiosa que, identificável nas origens do movimento cristáo, teria sobrevivido com particular força entre alguns grupos contemporâneos. Por tal motivo, o referido livro é dedicado à comunidade e liderança religiosas muito admiradas entre cristãos de esquerda, isto é, à "Igreja que está em São Félix do Araguaia e a seu Pastor Dom Pedro Casaldáliga porque aí a fé em Jesus Cristo Libertador inspira práticas verdadeiramente libertadoras". ${ }^{21}$ Como se sabe, São Félix do Araguaia, na Amazônia brasileira, registrava (e ainda registra) sangrentos conflitos fundiários. Situação que levou Casaldáliga a se opor tenazmente ao latifúndio e aos grandes fazendeiros, denunciando os frequentes assassinatos e violaçóes de direitos humanos, açôes violentas cujo alvo maior eram os agricultores pobres, agentes de pastoral, líderes comunitários e sacerdotes empenhados em causas populares. Já ao chegar à região, d. Pedro Casaldáliga redigiu mensagem pastoral que se tornaria célebre: "Uma Igreja da Amazônia em conflito com o latifúndio e a marginalização social", datada de outubro de 1971, época, aliás, mais sombria da última ditadura nacional.

O mesmo exercício analítico que norteia Jesus Cristo libertador - interpretar, com as lentes da teologia progressista latino-americana, personagem central à história cristã - é repetido por Leonardo Boff, poucos anos depois. Tal se deu no ensaio mariológico intitulado O rosto materno de Deus, lançado em 1979.22 De suas linhas, que buscam sistematizar vários

\footnotetext{
${ }^{19}$ Citada a seguir conforme a 12 edição, de 1988.

${ }^{20}$ BOFF, Leonardo. Jesus Cristo libertador. Petrópolis: Vozes, 1988, p. 31. Grifo meu.

${ }^{21}$ Ibidem, p. 5.

${ }^{22}$ E aqui utilizado em sua 4ª edição, de 1986.
} 
temas caros à reflexão católica sobre Maria — maternidade virginal, seu papel na mediação de graças, sua assunção ao Céu —, surge também a mulher pobre de Nazaré, que teria profetizado a libertação dos anawin, os menores do povo israelita.

A exemplo do esclarecimento feito em relação a Jesus Cristo libertador, deve ser dito que é impossível estender aqui a discussão sobre mais este ensaio de Boff. De novo, cabe frisar algo bem específico. Desejo, em primeiro lugar, ressaltar a eleição, por Boff, de seu objeto primário de análise - Maria, outra personagem central no panteão católico. Daí, deve-se ligar a mariologia de Boff a seu projeto de teologia militante. Assim, em $O$ rosto materno de Deus, ganha destaque a conexão ali contida entre reflexóes próprias da teologia e a defesa de demandas políticas progressistas contemporâneas. Ligação patente na forma pela qual Boff explica o Magnificat, o cântico que, conforme sustenta a tradição cristã, Maria recitou ao saber que conceberia o Messias. Cântico entoado por sem-número de fiéis, ao longo dos séculos; hino ressignificado por Boff, como será visto na sequência.

Conforme consignado em trecho do Magnificat reproduzido pelo teólogo brasileiro, Maria afirma que Javé "[d]errubou do trono os poderosos, e elevou os humildes". ${ }^{23}$ Gesto que, segundo exegese tradicional, celebraria o nascimento do Messias em família modesta. Leonardo Boff pretende ir além, integrando fé e compromisso político questionador da ordem estabelecida. Para ele, o Magnificat torna público que "O Deus bíblico não é um ídolo que enfeita (...) É um Deus vivo, cujo nome verdadeiro se chama Justiça, Santidade, Misericórdia para os que, injustamente, são oprimidos." ${ }^{24}$

Passagem reveladora: a teologia do entáo frei Boff, autorizada por particular interpretação dos textos bíblicos, une contemplação e apelo à ação. Ação que se apresenta como transformadora (“libertadora”). Atam-se, em registro contestador, espiritualidade cristã e mística da militância.

\section{Uma trilogia especial}

Havendo analisado, em clave progressista, as trajetórias de Jesus e Maria, Leonardo Boff avança em sua teologia, apreciando sua particular tradição religiosa, a franciscana. Creio ser mesmo possível propor que os mencionados ensaios cristológico e mariológico, publicados em 1972 e 1979 respectivamente, serão complementados pelo retrato que Boff traça do santo de Assis, fundador da Ordem onde ele permaneceu por décadas. Boff forja, entáo, especial conjunto, trio de obras amalgamadas por exercício comum: aquilatar e ressignificar, à luz dos preceitos da Teologia da Libertação, a importância de personagens referenciais ao cristianismo de matriz católica. Vale notar que este tipo de estudo teoló-

\footnotetext{
${ }^{23}$ BOFF, Leonardo. O rosto materno de Deus. Petrópolis: Vozes, 1986, p. 204.

${ }^{24}$ Ibidem, p. 207.
} 
gico, com claras implicaçóes políticas, também foi realizado em tradição diversa daquela da Igreja romana. Walter Altmann, destacado teólogo progressista luterano, dedicou ao "Pai da Reforma" o livro Lutero e libertação (1994), obra sintomaticamente apresentada por Leonardo Boff.

Ultimando a reinterpretação de personagens fundamentais a seu cristianismo, Boff dedicou dois livros àquele que, na expressão própria do meio eclesial em que vivia, tornou-se seu "Pai espiritual": Francisco de Assis: ternura e vigor, de 1981, e Francisco de Assis: a saudade do paraíso, de 1985. Publicadas quase em sequência, tais obras são absolutamente confluentes. Para a atual exposição, priorizo Francisco de Assis: a saudade do paraíso. Eleição motivada por três razôes principais. Em primeiro lugar, a obra escolhida, mantendo a mensagem central de Francisco de Assis: ternura e vigor, expóe sua argumentação de forma extraordinariamente concentrada. Há também o rico contexto de Francisco de Assis: a saudade do paraíso, que vem a lume meses após seu autor haver sido punido, pela Santa Sé, por alegados desvios doutrinários contidos no livro Igreja: carisma e poder. ${ }^{25}$ Sanção disciplinar que ordenava ao teólogo permanecer em silêncio por tempo não estabelecido. Na prática, a vaga ordem romana destituía Boff de sua cátedra no Instituto Teológico Franciscano, obrigando-o também a se afastar da redação da Revista Eclesiástica Brasileira, estando vetadas conferências, declaraçóes públicas e entrevistas. Mesmo as missas presididas por frei Leonardo deveriam ter homilias discretas. Restava ao teólogo a pesquisa e a escrita. Daí resultou Francisco de Assis: a saudade do paraíso, publicado ainda durante a vigência da sanção vaticana. Texto construído em sofisticado movimento para não violar as determinaçôes disciplinares recebidas. Texto que assumiu o papel de silencioso (porque impresso) libelo em favor da eclesiologia militante de seu autor, o que acrescenta ao livro interesse analítico ímpar. Em terceiro lugar, Francisco de Assis: a saudade do paraíso teve considerável impacto no cenário nacional, alcançando público mais diversificado que aquele tradicionalmente mantido por Boff. Basta dizer que a noite de autógrafos da obra, no Rio de Janeiro, foi reportada por importante telejornal local. Acrescente-se que o interesse do público foi majorado pelo fato de, em 1985, o Brasil ver terminada sua mais longa ditadura. Assim, junto àqueles que seguiam o ainda tenso debate político nacional, repercutiu fortemente o fato de Boff ter sido silenciado quando o país se libertava do arbítrio. Embora a redemocratização brasileira e a política doutrinária e disciplinar do papado dissessem respeito a realidades bem diversas, muitos, à época, manifestaram mal-estar por este descompasso entre as conjunturas nacional e eclesial.

\footnotetext{
${ }^{25}$ Neste ensaio, a crítica de Boff, antes dirigida ao sistema capitalista de produção, atinge a própria Igreja. Esta é questionada em sua organização como poder sacramental. Daí, Boff propõe a gênese de nova Igreja ("eclesiogênese"): mais aberta à participação de leigos e mulheres, mais próxima às camadas populares e suas demandas. Ver CAMURÇA, Marcelo. A militância de esquerda (cristã) de Leonardo Boff e Frei Betto: da Teologia da Libertação à mística ecológica. In: FERREIRA, Jorge; REIS, Daniel (Org.). Revolução e Democracia (1964 ...). Rio de Janeiro: Civilização Brasileira, 2007, p. 400-402.
} 
Esclarecida a fonte a ser explorada, passo a analisar a teologia política de Leonardo Boff a partir do Francisco de Assis modelado pelo teólogo brasileiro. Construçáo que confere ao Assisense papel duplamente notável: a de arauto do retorno da Igreja a seu estado de pobreza primitivo e também de santo protetor das lutas populares.

\section{A tradição transfigurada}

$\mathrm{Na}$ abertura de La citadelle intérieure, erudito comentário ao pensamento de Marco Aurélio, Pierre Hadot alertou para a ilusória clareza de Meditaçóes, obra onde aforismos e breves comentários se sucedem uns aos outros, sem ordem nítida. ${ }^{26} \mathrm{~A}$ sua maneira, Francisco de Assis: a saudade do paraíso também é, ele mesmo, um livro que pode contrariar juízos por sua suposta simplicidade.

À primeira vista, desde o título, está-se diante de literatura religiosa mais convencional. Opinião que prevalece quando se tem acesso à seguinte síntese de Francisco de Assis..., retirada do sítio pessoal de Leonardo Boff:

O livro comenta os quadros em arte naif de Nelson Porto [1950-1989], apresentando a singularidade de São Francisco como aquele homem que viveu com tanta inocência e amor para com a natureza que nos faz lembrar continuamente o paraíso. ${ }^{27}$

Enfim, em contato inicial, esquecendo-se do autor e do contexto no qual o livro foi escrito, Francisco de Assis... passaria por obra piedosa enriquecida por esmeradas gravuras. Obra que, reunindo preocupaçôes religiosas e estéticas, teria por propósito único analisar, à luz da fé, abundante iconografia referente ao santo assisense: ilustraçóes, estudos gráficos e apuradas reproduçôes de telas.

Impressão reforçada quando se coteja o livro de Boff com I fioretti ("As florezinhas"), coletânea de passagens da vida de Francisco e de seus discípulos imediatos. Como no florilégio medieval, em Francisco de Assis: a saudade do paraíso estão presentes muitos elementos da biografia do chamado poverello: a revelação divina, que teria ocorrido na capela de São Damião; a opção radical de Francisco pela pobreza e seu trabalho assistencial junto aos leprosos; a relação mística com Clara; o "Sermão aos Pássaros"; o episódio do lobo de Gubbio; a criaçáo do presépio, em Greccio; a recepção dos estigmas próximo da morte, no monte Alverne. Lá estão também outros marcos referenciais do pensamento franciscano: o Cântico do irmão Sol, algumas oraçóes atribuídas ao santo, seu testamento.

\footnotetext{
${ }^{26}$ Cf. in HADOT, Pierre. La citadelle intérieure. Paris: Fayard, 1997, p. 7.

${ }^{27}$ BOFF, Leonardo. Obra bibliográfica completa [última atualizaçáo em 2010]. Disponível em: <http://leonardoboff.com/site/publica/pub93-86.htm>. Acesso em: março de 2015.
} 
Entretanto, Francisco de Assis: a saudade do paraiso vai muito além da recordação celebrativa da herança franciscana. Frei Leonardo lembra de episódios fundamentais da saga do assisense, decifrando o que the parece ser seu sentido profundo com auxilio dos postulados da Teologia da Libertação. De outra forma, utilizando vocabulário próprio ao cristianismo: no texto em questáo, Boff transfigura a memória historicamente consolidada do franciscanismo.

Por importante, seja frisado: a releitura de Boff parte de texto convencional, aceito por todos na Igreja: I fioretti. Há mais. Boff, ao lançar mão de I fioretti, não somente apela à certa tradição cristã e franciscana, há séculos imortalizada (e também "petrificada") em texto. Ele procura acessar algo que julga ser o responsável pelo vigor do relato tradicional: a forma de sua construção:

O estilo [de I fioretti] é táo delicioso e característico que se transformou numa espécie de gênero literário, largamente utilizado neste livro [Francisco de Assis...]. O legendário se mistura com o factual no sentido de atualizar a mensagem franciscana. ${ }^{28}$

Assim, analogamente à liberdade encontrada no passado pelos redatores de I fioretti, que mesclaram fatos históricos da vida de Francisco e várias legendas que se somaram a eles, Boff se sente autorizado a operar outra união: entre o legado franciscano mais clássico e o cristianismo de libertação. Fusão que vê como necessária para atualizar — palavra tão cara aos discursos progressistas católicos desde o aggiornamento do Vaticano II — a mensagem vinda de Assis, adaptando-a à realidade latino-americana. Adaptação, emblematicamente, ilustrada pela arte de Nelson Porto. Como se sabe, naïf vem do latim nativus, significando "natural", "original". Haveria forma artística mais adequada para expressar a busca de um franciscanismo primevo (e, ao mesmo tempo, libertário)?

A apontada fusão entre tradicional relato franciscano e postulados centrais da Teologia da Libertação é discernível ao longo de todo texto de Francisco de Assis: a saudade do paraíso. Por limitaçóes espaciais, tal obra será ilustrada aqui a partir de trechos selecionados. Extratos que, tomando emprestado o estilo de I fioretti, remetem a episódios capitais no imaginário construído em torno do santo de Assis. Episódios retirados das mencionadas I fioretti, feitas modelo por Boff, e também de outras fontes primitivas do movimento franciscano, como as biografias do santo de Assis redigidas por Tomás de Celano e Boaventura de Bagnoregio. Enfim, nosso autor busca pisar em terreno conhecido para ir adiante em suas proposiçóes.

Retorno às seçóes escolhidas para resumir o argumento de Francisco de Assis: a saudade do paraíso. Sequência que é aberta com a imagem do Crucifixo de São Damião, ${ }^{29}$ obra anônima do século XII e, 800 anos passados, das mais reproduzidas peças religiosas do fransciscanismo. A razão para tamanha notoriedade é simples. Segundo os relatos primitivos, foi diante do Crucifixo de São Damião, exposto na igrejinha de mesmo nome, templo então

\footnotetext{
${ }^{28}$ BOFF, Leonardo. Francisco de Assis: a saudade do paraíso. Petrópolis: Vozes, 1985, p. 25. Grifo meu.

${ }^{29}$ Ibidem, p. 30.
} 
em ruínas, que Francisco, em crise espiritual, teve experiência mística determinante. Vinda dos lábios da imagem do Cristo pregado à cruz, ele teria ouvido uma voz que lhe pede: "Vai, Francisco, restaura minha Igreja que, como vês, está precisando de reparos." Sentença, a propósito, que serve de epígrafe ao livro em análise.

Interessante notar que Boff recorre à consolidada hagiografia de Francisco, porém é econômico nos detalhes. Do episódio místico pretensamente ocorrido em São Damião, o teólogo brasileiro apenas diz o essencial: nomeia o personagem envolvido, situa o local do evento, registra a mensagem sobrenatural falada e ouvida. Boff parece escrever para público já versado na legenda franciscana.

Porém, há mais: partindo da síntese de relato antigo, Boff desdobra o discurso. Trata-se, como já foi dito, de reler a legenda de Assis, incorporando teses caras à Teologia da Libertação. Assim, no texto que acompanha a reprodução do Crucifixo de São Damião ("A Cruz tem sempre dois lados”), Boff interpreta, pela fé, a morte na cruz de seu Cristo. Martírio cujo sentido seria "identificar-se com os crucificados da história. Eles nunca mais morrerão sós. Jesus morre crucificado com eles" ${ }^{30}$

Boff, deste modo, repete dos mais usuais temas do cristianismo progressista latino-americano: a identificação transtemporal entre um homem-Deus condenado ao suplício e a incontável multidão de pobres e excluídos nos países subdesenvolvidos. Para o teólogo:

Jesus não está só na cruz. Estão os seus seguidores. (...) Há também o exército de crucificados. Eles são invisíveis. Estão crucificados no outro lado. A cruz tem sempre dois lados, aquele do Mestre e aquele outro dos discípulos e de todos os sofredores deste mundo. ${ }^{31}$

Palavras que ilustram importante câmbio discursivo. Como é notório, o tema da Cruz ocupou lugar central ao longo dos dois mil anos da história cristá, tornando-se a própria cruz símbolo por excelência deste credo, sinal e esperança de cada fiel na redenção após a morte. No campo da especulação religiosa, em tempos modernos, firmou-se uma Theologia Crucis dirigida ao fiel singular, concentrada no problema da salvação individual. Redenção, de acordo com a fé cristá, propiciada pela morte e ressurreição do Messias, drama prefigurado pelo "Servo Sofredor" de Isaías (Is 53).

A esta compreensão, a Teologia da Libertação acrescenta outra, complementar ao entendimento anterior, comparando o calvário de Jesus à condição subumana de milhões na América Latina (e Terceiro Mundo). Situação que Boff chamará, em texto pouco posterior ao aqui priorizado, de "escândalo da pobreza". ${ }^{32}$ Surge, pois, na expressão dos intelectuais

\footnotetext{
${ }^{30}$ Ibidem, p. 31.

${ }^{31}$ Idem.

32 BOFF, Leonardo. A Igreja se fez povo: eclesiogênese, a Igreja que nasce da fé do povo. Petrópolis: Vozes, 1988, p. 17.
} 
cristãos liberacionistas, "o povo crucificado como lugar teológico". ${ }^{33}$ Desta forma, se a Jesus se atribui morte violenta e injusta, a miséria de tantos é também assinalada como essencialmente má e não desejada por Deus. Sob esta ótica, é compreendida a afirmação de Boff para seu Cristo, em poesia disposta na obra em análise: "Estás na cruz, irmão amado/ não por um plano sinistro traçado/ nos arcanos eternos do Pai." ${ }^{4}$ Avaliação que é estendida às desigualdades sociais que a Teologia da Libertação deseja denunciar, classificadas, pelo mesmo autor, de "injustiça [que] grita aos céus". ${ }^{35}$ Tal ponto é repetido exaustivamente por Boff e outros teólogos da libertação. Como nesse trecho de obra originalmente publicada em 1980:

(...) a pobreza constitui um mal: para a Bíblia é uma forma como a morte se manifesta na vida humana, porque sob a morte não se deve entender apenas o último momento da vida biológica, mas tudo que diminui, limita, humilha, ofende e encurta a existência humana. Semelhante pobreza contradiz o desígnio histórico de Deus. ${ }^{36}$

Isto posto, o Francisco de Assis retratado por Boff reforça compromissos progressistas a partir de Theologia Crucis diversa da personalista: "Francisco encontrou o Crucificado nos crucificados dos caminhos, nos hansenianos e nos pobres. Só então o Crucificado de São Damião lhe falou." 37

O leitor de Boff é lembrado da sucessão de episódios que, segundo as fontes medievais, tanto marcou Francisco em conflito interior. Ao jovem de Assis só fora concedido discernir como proceder, por intermédio da mensagem sobrenatural recebida na capelinha de São Damiáo, após encontrar-se com os mais desvalidos. Encontro que Boff recorda:

[Francisco] Um dia, andando a cavalo, encontrou-se com um leproso. De longe sentiu o odor purulento. Seu primeiro impulso foi dar meia-volta. Mas prosseguiu. (...) Apeia o cavalo. Vê as mãos carcomidas, os olhos escavados, a face ulcerada. Pausadamente lhe entrega uma esmola na mão e a beija ternamente. Como que voando no cavalo, repleto de doçura, se afasta (...). No

\footnotetext{
${ }^{33}$ A imagem do marginalizado e empobrecido como "crucificado" é especialmente cara a Jon Sobrino, outro formulador referencial da Teologia da Libertaçáo. Em variados textos e ocasiōes, Sobrino menciona o "povo crucificado", expressão que tomou emprestada do confrade jesuíta Ignacio Ellacuría, seu colega na Universidad Centroamericana, em San Salvador, assassinado por esquadrão de ultradireita. O próprio Boff celebrou a confluência entre ele e Sobrino. Confluência não apenas na produção teológica: tal como Boff o foi nos anos 1980, Sobrino será notificado disciplinarmente pela Santa Sé, em 2007. Ver em <http://www.sicsal.net/sobrino/BoffASobrino.html>, acesso em: abril 2015. Acrescente-se que a mesma ideia da crucificação de milhóes de miseráveis nos tempos atuais é retomada pelo teólogo franciscano Sinivaldo Tavares, em A Cruz de Jesus e o sofrimento no mundo, de 2002. Ir especialmente às páginas 153 e seguintes.

${ }^{34}$ BOFF, Leonardo. Francisco de Assis: a saudade do paraíso, op. cit., p. 29.

${ }^{35}$ Ibidem, p. 90.

${ }^{36}$ BOFF, Leonardo. Teologia do cativeiro e da libertação. Petrópolis: Vozes, 1998, p. 280-81.

${ }^{37}$ BOFF, Leonardo. Francisco de Assis: a saudade do paraíso, op. cit., p. 37.
} 
dia seguinte, se dirige ao leprosário (...). Permanece longo tempo com os doentes. Lava-lhes as feridas, abraça-os e os beija nos lábios, um a um. ${ }^{38}$

O teólogo, sem indicar formalmente a fonte, segue Tomás de Celano, autor das duas mais antigas biografias do santo: Vida primeira, de 1228, e Vida segunda, redigida entre 1246-1247. ${ }^{39}$ Escritos exemplares que Boff parece somente mimetizar, adotando dinâmica expositiva própria das hagiografias: Francisco pensa em fugir diante da provação ("Seu primeiro impulso foi dar meia-volta."); logra controlar-se ("Mas prosseguiu."), agindo de maneira virtuosa ("Pausadamente lhe entrega uma esmola na mão e a beija ternamente."); nobre modo de proceder que o santo repete por longo período ("Permanece longo tempo com os doentes ...”).

No entanto, há bem mais em jogo. Boff reproduz Celano para legitimar determinado discurso teológico. Na mesma seção do livro em foco, ele opina sobre o dilema do Assisense em relação aos hansenianos: "Ou [Francisco] assume o leproso ou jamais será servidor do Servo sofredor" ${ }^{40}$ Isto posto, Boff arremata, chegando a ponto crucial para a presente exposição: "Francisco trocou de lugar social. Converteu-se ao Crucificado e assumiu aqueles que mais o representam neste mundo, os mais pobres dos pobres, os leprosos." ${ }^{\prime 1}$

É necessário cotejar a canônica franciscana com a apropriação que Boff faz dela. Os documentos mais antigos dispóem, em sequência, dois eventos: em primeiro lugar, é relatada a ação de Francisco junto aos leprosos. Na continuação, lê-se o relato da epifania ocorrida na pequena capela arruinada de Sáo Damião, revelação que auxilia Francisco a discernir sua nova missão cristã (“restaura minha Igreja”, missão, de início, entendida literalmente). E, com base na tradicional literatura franciscana, o que faz Leonardo Boff? O teólogo extrai dela novo sentido, radicalizando o conceito de conversáo (troca de lugar social). Ele associa a adoção de fé privada à certa prática, à admissão de determinado papel a cumprir entre os homens, prioritariamente entre aqueles das classes sociais mais baixas. Em suma: para Boff, o restauro da Igreja, tanto ontem como hoje, está ligado ao cumprimento de tal missão, tarefa onde credo religioso e dada práxis são tomados por complementares.

Lembre-se que, tradicionalmente, a conversão ao cristianismo, religião de natureza apologética, implicava o comprometimento do novo fiel em testemunhar o credo assumido, difundindo-o pela pregação e praticando obras de caridade. Boff irá redirecionar o foco: mais que a conquista de toda a sociedade para a Igreja e o socorro emergencial aos necessitados, sua ideia de conversão como câmbio de lugar social firma outro compromisso, cruzando cristianismo e militância política, ambos lidos de maneira progressista.

\footnotetext{
${ }^{38}$ Ibidem, p. 53.

${ }^{39}$ Para o episódio em foco, ver Vida primeira, 7 e Vida segunda, 6. Obs.: A canônica franciscana foi consultada em SILVEIRA, Ildefonso; REIS, Orlando dos. São Francisco de Assis: escritos e biografias de Sáo Francisco de Assis. Petrópolis: Vozes/CEFEPAL, 1988.

${ }^{40}$ BOFF, Leonardo. Francisco de Assis: a saudade do paraíso, op. cit., p. 53.

${ }^{41}$ Ibidem, p. 53, grifo meu.
} 
Já em livro pouco anterior à publicação de Francisco de Assis: a saudade do paraiso, Boff registrara este ponto. Francisco, filho de burguês rico, optou por se tornar pobre como os pobres - e náo com ou para os pobres. ${ }^{42} \mathrm{E}$, em outro escrito do mesmo período, nosso autor explica a ideia de conversão aos mais necessitados, recorrendo à história da Igreja. No caso desta instituição, afirma, sua "estratégia histórica" esteve, por séculos, centrada na associação com as classes dirigentes, planejando

(...) converter os filhos dos poderosos (econômica, social, ideológica e politicamente) para que, convertidos, humanizassem as relaçôes entre as classes e ajudassem os pobres em suas necessidades. ${ }^{43}$

Estratégia que, para Boff, seria superada por outra, condizente com a eclesiologia progressista da América Latina. Converter-se, diz ele, é optar pelos pobres (ainda que estes, muitas vezes, não sejam conceitualmente bem definidos em seus escritos, são apenas "pobres"):

Agora a opção/conversão aos pobres implica que a Igreja se volva de maneira mais direta para as camadas populares (...). Tudo isto exige uma mudança/conversão das mentalidades e práticas eclesiais. ${ }^{44}$

Projeta-se daí, por conseguinte, um cristianismo contestador, que, segundo seus partidários, requer da Igreja institucional e de todos os fiéis a conversão a práticas religiosas e políticas consideradas "libertadoras". Eclesiologia que vai possibilitar, por exemplo, a gênese e difusão do mais célebre fenômeno cristão progressista brasileiro no século XX: as Comunidades Eclesiais de Base (CEBs), redes pastorais com base popular, em áreas urbanas e rurais, onde se unem reflexão sobre a fé e reivindicação de melhores condiçốes de vida. Mobilização, seja acrescentado, que fará cristãos atuantes nestas CEBs terem participação destacada na fundação do Partido dos Trabalhadores (PT), em 1980.

Recapitulando: Leonardo Boff e outros adeptos da Teologia da Libertação propóem registro de cristianismo que se opóe ao sistema capitalista e à aliança secular da Igreja com as classes dirigentes. Associação política e sistema econômicos que teriam sido responsáveis pela reprodução de situação de pobreza e exclusão social, status quo denunciado como "antievangélico" pelos cristãos liberacionistas. Por isso, segundo estas mesmas vozes, na América Latina e no Terceiro Mundo, a conversão à fé e, mais que isso, a cotidiana confirmaçáo da fé se dão no encontro com as classes populares (definidas, muitas vezes, sem o rigor necessário, como "os

\footnotetext{
${ }^{42}$ Ver BOFF, Leonardo. Francisco de Assis: ternura e vigor, Petrópolis: Vozes, 1991, p. 85-88.

43 BOFF, Leonardo. O caminhar da Igreja com os oprimidos, op. cit., p. 135. Interessante observar que Boff, ao menos neste trecho, não menciona os interesses da Igreja em sua própria perpetuação, facilitada pelos vínculos estabelecidos com o poder.

${ }^{44}$ Ibidem, p. 135. Grifo meu.
} 
excluidos" ou "os pobres") e com aquelas que seriam suas prementes aspiraçôes. Encontro que, para Boff, teve seu paradigma em Francisco de Assis.

De tudo isso decorre apelo missionário que une mística cristã e militância de esquerda. União crítica de intervenções meramente caritativas ou mesmo reformistas típicas do apostolado social católico. Pode-se dizer que se firma, então, novo paradigma de fiel (e de intelectual) cristão: aquele que, em nome da fé, converte-se à ação que se apresenta como libertadora.

Esta concepção da fé cristã e de suas consequências políticas mobilizou adversários. Opositores que acusavam a Teologia da Libertação de tentar transformar religião em ideologia. Temor que contribuiu decisivamente no processo doutrinário enfrentado por Leonardo Boff, em 1984, culminando, um ano depois, com sua punição. Em 1996, mais de uma década passada da sanção ao brasileiro, o então cardeal Joseph Ratzinger, responsável pela inquirição do frade Boff em Roma, declarou a jornalista alemão: "Quanto à teologia da libertação (...) Havia o risco de uma politização da fé que a teria impelido para uma partidarização política irresponsável e que teria destruído o que é especificamente religioso." ${ }^{\text {"45 }}$ Crítica incisiva, ela explicita o que estava em jogo para muitos católicos conservadores durante o longo papado de João Paulo II (1978-2005): preservar a Igreja da infiltraçáo ideológica de esquerda, presente na Teologia da Libertação, e do que seriam suas funestas implicaçóes relativas à manutenção da unidade eclesial. Tarefa da qual dependia, em última análise, ainda de acordo com a ótica prevalente no Vaticano, a sobrevivência da própria fé católica.

\section{O sonho em tempos de tormenta}

Da parte de Roma, as veementes objeçôes teóricas à teologia militante de Leonardo Boff resultaram em censura concreta: o silenciamento compulsório do autor, mesmo que traduzido na forma de um eufemismo ("silêncio penitencial", obsequioso). ${ }^{46}$

Para Boff, urgia responder, cuidando de não violar as determinaçôes superiores. ${ }^{47}$ Réplica contida em Francisco de Assis: a saudade do paraíso, como afirmei nestas linhas. Refutação intensificada em singular trecho desse livro. Seção que opera dois movimentos distintos. $\mathrm{O}$ primeiro já identificado aqui: associar as teses da Teologia da Libertação ao espírito francis-

\footnotetext{
${ }^{45}$ RATZINGER, Joseph. O Sal da Terra: o cristianismo e a Igreja católica no século XXI, Rio de Janeiro: Imago, 2005, p. 75.

${ }^{46}$ Modus operandi, aliás, já presente na fase de instrução romana do processo de Boff: o interrogatório a que ele se submeteu foi classificado, nos documentos oficiais e comunicados de imprensa vaticanos, como "colóquio".

${ }^{47}$ Boff amparou-se em princípio legal admitido pelo Direito Canônico. Procedimento informado ao Ministro Geral da Ordem Franciscana (autoridade máxima da mesma), em carta privada de 8 de maio de 1985, redigida em língua espanhola: "[...] todo lo que no esté estrictamente prohibido, voy a ejercerlo en el sentido de la eclesialidad siempre necesaria [...]". Cf. "Carta-Resposta de Frei Leonardo Boff ao Pe. Geral John Vaughn, O.F.M.”, in: MOVIMENTO NACIONAL DOS DIREITOS HUMANOS. Roma Locuta. Petrópolis: Vozes/Serviço de Intercâmbio Nacional, 1985, p. 147.
} 
cano mais antigo. Complementando a carga do contra-ataque, Boff adverte os críticos desta eclesiologia latino-americana.

$\mathrm{Na}$ aludida passagem, Leonardo Boff relata sonho que teria tido frei Ludovico, apresentado como frade próximo a Francisco. Certa noite, em sonho, frei Ludovico avistou Santa Maria dos Anjos, uma das capelas restauradas por Francisco, também chamada de Porciúncula, devido a suas diminutas dimensōes ( $7 \times 4$ metros). Segundo a tradição, esse era o local predileto do chamado poverello. ${ }^{48} \mathrm{Ali}$, ele decidiu viver na pobreza mais radical, fundando sua Ordem. Ali, faleceu nu sobre a terra. ${ }^{49}$

E o que Boff narra a seu leitor? No sonho de frei Ludovico, ergue-se da Porciúncula:

(...) árvore imensa. (...) Frei Ludovico fixou melhor o olhar pois entrevia no tronco escuro a figura franzina de S. Francisco. Os braços abertos entravam ramos adentro. ${ }^{50}$

A imagem impressiona, faz lembrar o realismo fantástico latino-americano. Uma árvore, enraizada sob o mesmo solo onde o santo de Assis fundara sua Ordem mendicante e sobre o qual falecera desnudo, irrompe, prodigiosamente, rumo ao Alto. Imensa, assombrosa árvore que, tendo a imagem de Francisco maravilhosamente gravada em seu tronco,

[a]rojava-se ao céu como as castanheiras, retas e robustas da Amazônia. Escuro era o tronco. Clara a copa como o alvorecer por sobre a floresta tropical. De todos os ramos irrompiam flores multicores. ${ }^{51}$

A menção à vegetação dos trópicos salta duplamente aos olhos. Em primeiro lugar: por ser a Amazônia desconhecida do europeu medievo, tal descrição não pode constar de qualquer fonte franciscana primitiva..$^{52} \mathrm{~A}$ referência à pujante flora amazônica também chama a atenção por recordar ao leitor — ao menos àquele informado da trajetória de Boff — a crise que este enfrentou quando retornou da Europa, após anos de ausência. Sofrimento diante

\footnotetext{
${ }^{48}$ CELANO, Vida Primeira, 106, in: SILVEIRA, Ildefonso; REIS, Orlando dos. São Francisco de Assis: escritos e biografias de São Francisco de Assis. Petrópolis: Vozes/CEFEPAL, 1988.

${ }^{49}$ BOAVENTURA, Legenda Maior, 14. Boaventura também foi consultado em SILVEIRA, Ildefonso; REIS, Orlando dos. São Francisco de Assis: escritos e biografias de São Francisco de Assis, op. cit.

${ }^{50}$ BOFF, Leonardo. Francisco de Assis: a saudade do paraíso, op. cit., p. 35.

${ }^{51}$ Ibidem, p. 35.

${ }^{52}$ Tampouco frei Ludovico é mencionado nas fontes que acessei. Creio que, acrescentando personagem fictício a seu texto, Boff homenageia o frade Ludovico Gomes de Castro, religioso que, durante muitos anos, dirigiu a editora Vozes. Em sua gestão, frei Ludovico foi o responsável pela então arriscada decisão de publicar o livro Brasil: nunca mais, o mais completo e documentado estudo sobre a utilização de tortura, por agentes do Estado, durante a última ditadura brasileira. Publicação (feita meses após a posse de governo civil, quando não era clara a reação de partidários do antigo regime a ela) recomendada, em parecer, pelo próprio Boff. Para maiores esclarecimentos, ver WESCHLER, Lawrence. Um milagre, um universo: o acerto de contas com os torturadores. São Paulo: Companhia das Letras, 1990, p. 75.
} 
da miséria tropical que fez o teólogo questionar o saber acadêmico adquirido na Alemanha, conforme testemunho citado acima.

Pelo que se disse, creio que nosso autor, deste turno acrescentando pistas que apontam para sua própria biografia, pretende, novamente, justapor franciscanismo primitivo e Teologia da Libertação. Afinal, a situaçáo de impasse que Boff recorda ter vivido no Amazonas apresenta paralelo com o que teria ocorrido a Francisco de Assis, na capelinha de Sáo Damião. Diante do famoso crucifixo, Francisco, após experiência mística, entendeu ter recebido a incumbência de reconstruir a Igreja. Tarefa associada à "troca de lugar social" segundo o entendimento de Leonardo Boff. Quanto a este último, ele declarou ter localizado, em sua vivência de Manaus, o início das indagaçóes intelectuais que o levaram a redirecionar sua reflexão e prática de fé, perfilando-se entre os formuladores da Teologia da Libertação. Nova missão que Boff concebe como exercício de fidelidade ao espírito franciscano original.

Confirmando o já disposto e de volta ao sonho citado em Francisco de Assis: a saudade do paraiso, Boff narra que, depois de muito refletir, frei Ludovico decifrou o significado do sonho, tomado por revelação celestial:

A missão de Francisco não se esgotou na reconstrução de igrejas nem na fundação da Ordem Franciscana com todos os seus ramos. Seu espírito evangélico tem a missão de perenemente recriar a Igreja a partir daquela única fonte que legitimamente permite refazer sempre de novo a Igreja: Jesus pobre e seu evangelho cujos primeiros destinatários são os pobres..$^{53}$

Em resumo: para a Teologia da Libertação, a atualização do cristianismo, no limiar do século XXI, em sociedade cada vez mais secularizada e desigual, passava pela ativação constante da característica mais autêntica (por primitiva) deste credo: a opção pelos pobres, eleição evangélica ratificada por Francisco de Assis.

Movimento que Leonardo Boff propõe ser paradigmático para a Igreja, sempre em processo de recriação e revitalização. Assim, a associação entre os ideais de Francisco de Assis, personagem canonizado pela Igreja, $e$ a teologia de Boff, questionada pela mesma instituição, guardaria propósito suplementar. O intelectual brasileiro, sem quebrar o silêncio a que fora obrigado, assevera, tendo seu público por testemunha, que anatematizá-lo e a sua teologia significa condenar igualmente o santo de Assis.

\section{Conclusão}

Para finalizar, dois movimentos. Primeiro, há que concluir o argumento que motivou e conduziu o corrente estudo, a análise da imagem que Leonardo Boff cunhou do santo fundador de sua então Ordem religiosa. Por fim, avançando algumas décadas, cabe resumir

${ }^{53}$ BOFF, Leonardo. Francisco de Assis: a saudade do paraíso, op. cit., p. 35-36. 
a interpretação de Boff acerca da eleição de Jorge Mario Bergoglio ao trono de São Pedro e sobre a inédita opção do novo pontífice pelo nome Francisco.

\section{Säo Francisco segundo Leonardo Boff}

Analisou-se aqui a imagem de Francisco de Assis modelada pelo teólogo Leonardo Boff, representação defendida por seu autor como fiel às fontes franciscanas mais primitivas. Construção essa efetuada em difícil conjuntura, aquela da repressão romana à Teologia da Libertação e enquanto o então frei sofria severa censura da parte da mais alta instância doutrinária católica romana, nos anos 1980. Tratava-se, para Boff, de defender, de uma só vez, a herança espiritual do poverello, a Teologia da Libertação latino-americana, a si mesmo e a seu projeto eclesiológico. E Boff exalta, em Francisco de Assis, o padroeiro das causas populares, espécie de antecipação medieval daquilo que a Teologia da Libertação entende por exemplaridade cristá. Modelagem válida para a Igreja e cada fiel, todos instados à mobilização e luta por justiça social.

Vale recordar a imagem do rio, empregada nos discursos teleológicos cristãos para descrever o percurso da própria Igreja através dos séculos. ${ }^{54}$ Representaçáo igualmente oportuna, creio, para ilustrar o movimento sugerido em Francisco de Assis: a saudade do paraíso. Nesta obra, Leonardo Boff parte dos textos que petrificaram a memória do poverello para trazê-lo ao leitor contemporâneo. Das fontes de Assis à foz, à praça pública brasileira. Das fontes à foz, como vigorosa torrente, depositando, ao longo do caminho, o que Boff acredita ser o húmus necessário - o compromisso do cristão com os mais humildes — para a gênese de sociedade radicalmente nova.

\section{Leonardo Boffe o papa Francisco}

É exatamente a presença militante de Boff na praça pública - e a maneira deste conceber a Teologia como exercício de fé e articulação política - que continuará incomodando autoridades da Santa Sé. Em 1992, antevendo o que seria a segunda sanção disciplinar vinda de Roma, o frei brasileiro renuncia ao presbiterato e deixa sua Ordem religiosa. Logo após,

\footnotetext{
${ }^{4}$ A metáfora do rio não está entre as mais comumente associadas à Igreja. "Esposa de Cristo" e "Ramos da Videira", por exemplo, são imagens bem mais frequentes até por terem sido consignadas nos textos bíblicos (ver, respectivamente, para os dois casos citados, Ap 21, 9-10 e Jo 15, 5-6). Contudo, a imagem da Igreja (ou de suas várias denominações) como um rio foi utilizada, no universo cristáo, por fiéis vindos de diferentes tradições cristãs, como é o caso do líder católico brasileiro Alceu Amoroso Lima e do scholar Gregory J. Riley, que leciona exegese do Novo Testamento na Claremont School of Theology (metodista). Para Amoroso Lima, ver Em busca da liberdade. Rio de Janeiro: Paz e Terra, 1974, p. 161. E, para Riley, ver The river of God: a new history of Christian origins. Nova York: HarperCollins, 2003, p. 1-21.
} 
Boff assume a cátedra de Filosofia e Ética, em universidade estatal do Rio de Janeiro (atividade da qual se aposentou há alguns anos), ocupando-se também com conferências e cursos, no Brasil e no exterior.

Câmbio e permanência: desde os anos 1990, ele, já como teólogo leigo e ainda tributário da herança do Assisense, segue participando em debates de assuntos contemporâneos. Nessas discussóes públicas, ele, com frequência, faz uso do pensamento atribuído ao poverello, sempre lido pela ótica do chamado cristianismo libertador.

Tal é o caso, por exemplo, do engajamento de Boff na discussão sobre o meio ambiente e na defesa de desenvolvimento social e ecologicamente sustentável. Militância que, retomando e ampliando intuiçôes mais antigas do autor, é organizada em Ecologia, mundialização, espiritualidade: a emergência de um novo paradigma (1993). Obra na qual Francisco de Assis é definido como "arquétipo ocidental da atitude ecológica" (BOFF, 1993, p. 52). Posteriormente, Boff irá advogar novo paradigma ecológico noutros trabalhos, como em Do iceberg à Arca de Noé: o nascimento de uma ética planetária (2010).

Assuntos católicos, em geral, e da Santa Sé, em particular, também continuaram a ser examinados por Boff, apesar de seu desligamento do ministério sacerdotal. E, novamente, em suas declaraçóes, ele mantém inequívoco vínculo com o franciscanismo.

Crítico incisivo dos pontificados de João Paulo II e Bento XVI, o teólogo tornou-se entusiasta da eleição ao papado do arcebispo argentino Bergoglio. Apoio expresso, em entrevistas, logo que o resultado do Conclave tornou-se conhecido. Apoio justificado no mais recente livro do intelectual em questáo, Francisco de Assis e Francisco de Roma: uma nova primavera na Igreja? (2013). Segundo o ensaísta brasileiro, Bergoglio, autonomeando-se em homenagem ao poverello, abraçou temas e objetivos caros à Teologia da Libertação: "Francisco não é um nome. É um projeto de Igreja, pobre, simples, evangélica e destituída de todo o aparato" (BOFF, 2013, p. 28)

É revelador que, na abertura de Francisco de Assis e Francisco de Roma, seja recordada, nos seguintes termos, a origem do novo pontífice: "vindo da periferia do mundo" (BOFF, 2013, p. 7). Aqui, Boff, sem dizê-lo, ecoa o próprio papa que, em sua primeira bênção Urbi et Orbi, apresentou-se ao público que enchia a Praça de Sáo Pedro como alguém que chegava "quase do fim do mundo". Interessante notar que o brasileiro vai além de mimetizar o novo papa. Boff, ao evocar a proveniência de Bergoglio, prefere, como citado acima, a expressão "periferia do mundo", muito comum entre formuladores da Teologia da Libertação para descrever o lugar social deste pensar.

Contudo, Boff não transforma Bergoglio em adepto do cristianismo liberacionista, bem sabe que o prelado argentino, em seu país, não esteve próximo desta eclesiologia. Aliás, para o intelectual em lume, a filiação formal a determinada escola teológica pouco importaria. Basta, afirma Boff, ser favorável à libertação efetiva dos empobrecidos - aliar-se a estes na superação "da fome, da miséria, da degradação moral" (BOFF, 2013, p. 47). Compromisso 
assumido pelo pontífice: "o Papa Francisco fez esta opção pelos pobres (...) e disse isso claramente (...): 'Como eu gostaria de uma Igreja pobre para os pobres'” (BOFF, 2013, p. 47-48.) Assim, antes que vincular Bergoglio à Teologia da Libertação, tratar-se-ia de associar o novo líder católico ao espírito franciscano mais original. O papa, sustenta Leonardo Boff, "explicitamente se religa à figura de São Francisco" (BOFF, 2013, p. 54.) Na sentença destacada, a escolha verbal não deve passar despercebida. Em vez de simplesmente valer-se do verbo ligar, o que seria mais próprio, Boff opta pelo verbo religar, do qual, como se sabe, deriva a palavra religião. Deste modo, o ex-frade tenciona valorizar — e, a sua maneira, sacralizar a identificação de Bergoglio com o poverello.

E, lembra o teólogo brasileiro, o santo de Assis e o atual bispo de Roma estão conectados igualmente na tribulação: aquele viveu a crise espiritual da Baixa Idade Média; este, a da Modernidade. Ambos tomaram a si a tarefa de restaurar a Igreja. Empresa hercúlea, que faz Boff questionar se o novo papa triunfará em seus planos eclesiais reformadores, vencendo críticos e adversários, sobretudo no Vaticano. A resposta: "Estimo que [o papa Francisco] saberá ter mão firme e não lhe faltará coragem para seguir (...) para restaurar de fato a credibilidade da Igreja e devolver o fascínio pela figura de Jesus" (BOFF, 2013, p. 65.)

Atente-se, por fim, à significância do verbo estimar, empregado nessa passagem. Nela, estimar quer dizer avaliar. Fica consignado, entáo, cálculo pessoal de Boff: ele considera que o novo pontífice terá força suficiente para dobrar adversários de seu projeto restaurador. Há mais. Tal projeção de cenário se traduz em esperança, sentimento associado a outro sentido possível do verbo estimar: desejar. Boff, fiel à memória do fundador de sua antiga Ordem religiosa, deseja sucesso ao papa Francisco. Isto é, Leonardo Boff estima êxito ao jesuíta que, inaugurando seu pontificado, proclamou, para a "Cidade e o Mundo", a atualidade da legenda de Assis.

\section{Referências bibliográficas}

ALTMANN, Walter. Lutero e Libertação: releitura de Lutero em perspectiva latino-americana. São Paulo: Ática; São Leopoldo: Sinodal, 1994.

AMOROSO LIMA, Alceu. Em busca da liberdade. Rio de Janeiro: Paz e Terra, 1974.

BOFF, Leonardo. O caminhar da Igreja com os oprimidos: do Vale de Lágrimas à Terra Prometida. 2. ed. Petrópolis: Vozes, 1998. 1. ed. 1980.

. Francisco de Assis: ternura e vigor. 5. ed. Petrópolis: Vozes, 1991. 1. ed. 1981.

. Francisco de Assis: a saudade do paraíso. Petrópolis: Vozes, 1985.

. Francisco de Assis e Francisco de Roma: uma nova primavera na Igreja?. Petrópolis:

Vozes, 2013. 
. Igreja: carisma e poder: ensaios de eclesiologia militante. Petrópolis: Vozes, 1981.

. A Igreja se fez povo: eclesiogênese, a Igreja que nasce da fé do povo. 2. ed. Petrópolis: Vozes, 1988. 1. ed. 1986.

. Jesus Cristo libertador: ensaio de Cristologia crítica. 12. ed. Petrópolis: Vozes, 1988. 1. ed. 1972.

Obra bibliográfica completa. Disponível em: <http://leonardoboff.com/site/ publica/pub93-86.htm>. Acesso em: 22 maio 2012.

. O rosto materno de Deus: ensaio interdisciplinar sobre o feminino e suas formas religiosas. 4. ed. Petrópolis: Vozes, 1986. 1. ed. 1979.

. Teologia do cativeiro e da libertaçâo. 6. ed. Petrópolis: Vozes, 1998. 1. ed. 1980.

BOFF, Leonardo; BOFF, Clodovis. Como se faz Teologia da Libertação? Petrópolis: Vozes, 1986.

BOFF, Leonardo et al. O que ficou... balanço aos 50. Petrópolis: Vozes, 1989.

BROWN, Peter. The Cult of Saints: its rise and function in Latin Christianity. Chicago: The University of Chicago Press, 1982.

CAMURÇA, Marcelo. A militância de esquerda (cristã) de Leonardo Boff e Frei Betto: da Teologia da Libertação à mística ecológica. In: FERREIRA, Jorge; REIS, Daniel (Org.). Revolução e Democracia (1964 ...). Rio de Janeiro: Civilização Brasileira, 2007. (Coleção Esquerdas no Brasil, v. 3).

CAROLI, Ernesto (Org.). Dicionário Franciscano. 2. ed. Petrópolis: Vozes: CEFEPAL, 1999. 1. ed. 1993.

COX, Harvey. The Silencing of Leonardo Boff: the Vatican and the future of world Christianity. Oak Park: Meyer Stone Books, 1988.

DELUMEAU, Jean; COTTRET, Monique. Le Catholicisme entre Luther et Voltaire. Paris: PUF, 1996.

FRUGONI, Chiara. Vida de um homem: Francisco de Assis. São Paulo: Companhia das Letras, 2011.

GIBELLINI, Rosino (Org.). Frontiers of Theology in Latin America. Maryknoll: Orbis Books, 1983.

GUIMARÃES, Juarez (Org.). Leituras críticas sobre Leonardo Boff. Belo Horizonte: Editora UFMG, 2008.

HADOT, Pierre. La citadelle intérieure: introduction aux Pensées de Marc Aurèle. Paris: Fayard, 1997.

IGREJA CATÓLICA. Documentos de Pio XI. São Paulo: Paulus, 2004.

KOTSCHO, Ricardo et al. Viagem ao coração do Brasil. São Paulo: Scritta, 1994. 
LE GOFF, Jacques. São Francisco de Assis. Rio de Janeiro: Record, 2001.

LIBÂNIO, João Batista. Igreja Contemporânea: encontro com a modernidade. São Paulo: Loyola, 2000.

LOWENTHAL, David. The past is a foreign country. Cambridge: Cambridge University Press, 1985.

LÖWY, Michael. A guerra dos deuses: religião e política na América Latina. Petrópolis: Vozes, 2000.

MOVIMENTO NACIONAL DOS DIREITOS HUMANOS. Roma Locuta: documentos sobre o livro Igreja: Carisma e Poder de Frei Leonardo Boff. Petrópolis: Vozes/Serviço de Intercâmbio Nacional, 1985.

OLIVEROS MAQUEO, Roberto. Liberación y teología: génesis y crecimiento de una reflexión (1966-1976). Cidade do México: CHR, 1977.

RATZINGER, Joseph. O sal da terra: o cristianismo e a Igreja católica no século XXI: diálogo com Peter Seewald. 2. ed. Rio de Janeiro: Imago, 2005. 1. ed. 1997.

RILEY, Gregory. The river of God: a new history of Christian origins. Nova York: HarperCollins, 2003.

ROBSON, Michael (Ed.). The Cambridge Companion to Francis of Assisi. Cambridge: Cambridge University Press, 2012.

SERBIN, Kenneth. Needs of the Heart: a social and cultural history of Brazil's clergy and seminaries. Notre Dame: University of Notre Dame Press, 2006.

SILVEIRA, Ildefonso; REIS, Orlando dos. São Francisco de Assis: escritos e biografias de São Francisco de Assis. Crônicas e outros testemunhos do primeiro século franciscano. 5. ed. Petrópolis: Vozes/CEFEPAL, 1988. 1. ed. 1981.

TAVARES, Sinivaldo S. A Cruz de Jesus e o sofrimento no mundo: a contribuição da Teologia da Libertação latino-americana. Petrópolis: Vozes, 2002.

TIME MAGAZINE. Millennium Top Ten. Disponível em: <http://content.time.com/time/ magazine/article/0,9171,976745,00.html>. Acesso em: 14 jul. 2012.

VARAZZE, Jacopo. Legenda Áurea: vida de santos. São Paulo: Companhia das Letras, 2003. VAUCHEZ, André. François d'Assise: entre histoire et mémoire. Paris: Fayard, 2009.

WESCHLER, Lawrence. Um milagre, um universo: o acerto de contas com os torturadores. São Paulo: Companhia das Letras, 1990. 